\title{
Article \\ Combined Shear-Tension Loading of Composite Dowels in Cracked Concrete-Experimental Investigations and Design
}

\author{
Georgios Christou $^{1, *}$, Kevin Wolters ${ }^{2}$, Jan Ungermann ${ }^{1}\left[\right.$, Martin Classen ${ }^{1}\left(\mathbb{D}\right.$ and Josef Hegger ${ }^{1}$ \\ 1 Institute of Structural Concrete, RWTH Aachen University, 52062 Aachen, Germany; \\ jungermann@imb.rwth-aachen.de (J.U.); mclassen@imb.rwth-aachen.de (M.C.); \\ jhegger@imb.rwth-aachen.de (J.H.) \\ 2 Institute of Steel Construction, RWTH Aachen University, 52062 Aachen, Germany; \\ k.wolters@stb.rwth-aachen.de \\ * Correspondence: gchristou@imb.rwth-aachen.de
}

Citation: Christou, G.; Wolters, K.; Ungermann, J.; Classen, M.; Hegger, J. Combined Shear-Tension Loading of Composite Dowels in Cracked Concrete-Experimental Investigations and Design. Appl. Sci. 2022, 12, 1449. https://doi.org/ 10.3390/app12031449

Academic Editor: André Furtado

Received: 25 December 2021

Accepted: 27 January 2022

Published: 29 January 2022

Publisher's Note: MDPI stays neutral with regard to jurisdictional claims in published maps and institutional affiliations.

Copyright: (c) 2022 by the authors. Licensee MDPI, Basel, Switzerland. This article is an open access article distributed under the terms and conditions of the Creative Commons Attribution (CC BY) license (https:// creativecommons.org/licenses/by/ $4.0 /)$.

\begin{abstract}
The importance of slim decks has led engineers to the exploration of high-strength materials and also of innovative shallow shear connectors, such as composite dowels in the case of composite constructions. Minimizing the overall slab depth often leads to composite girders being weakened by means of web openings that are necessary for installations such as ventilation ducts. Depending on the geometrical and loading conditions, some of the shear connectors are subjected to a combination of tensile and shear forces. However, the load-bearing behaviour of these connectors has only been rudimentarily investigated in the case of shear-tensile interaction. In addition, the load-bearing capacity of composite dowels under combined tensile and shear forces has not been investigated in cracked concrete. Earlier investigations under pure shear and pure tensile loading indicate a dependence of the connectors' load-bearing behaviour on the crack width, so that under combined loading, a similar influence is expected. In this paper, experimental investigations on composite dowels in transversely cracked concrete under systematically varied shear-tension loading combinations are presented. Hereby, predefined crack widths and patterns were considered using a special test rig. Finally, a design approach for concrete failure of composite dowels under shear-tension loading is proposed based on the test results.
\end{abstract}

Keywords: composite dowels; shear-tension interaction; cracked concrete; design

\section{Introduction}

The interconnection of steel-concrete composite girders can be achieved by means of shear connectors such as headed studs, perfobond connectors, composite dowels, and other suitable structural elements capable of transferring shear and tensile forces. While high stiffness is required from the connectors to minimize the deflection of composite girders, they must also be ductile in order to allow for force redistribution within the composite joint and thus a plastic design. Composite dowels possess both these properties and are therefore favoured increasingly both in building [1-6] and bridge [7-16] constructions. These innovative shear connectors are cut into the steel web or into the flanges of steel girders and positioned within the concrete slab, as shown in an example in Figure 1a or Figure 1c. Other possibilities for implementing composite dowels, such as welding a prefabricated composite dowel strip onto a steel flange, are also possible. Composite dowels are currently approved in Germany [17], while a European technical specification is currently being drafted.

While the influence of both combined shear and tensile loading [18-20] and damaged (cracked) concrete [21-23] has been investigated isolated, the two are often found simultaneously, as shown in two common examples in Figure 1b,c. In the former, the plastic hinges forming in the edges of web openings lead to significant curvature and cracks in the concrete belt, while the dowels in that region are subjected to high tensile or compressive 
forces, in addition to shear forces due to the composite action of the girder. Similar research has been conducted for prestressed concrete beams with openings [24]. In the case of a halved steel girder used as external reinforcement and positioned in the lower part of the web of a T-sectioned concrete beam, as shown in Figure 1c, the dowels must transfer both shear and tensile loads. As expected, within this region of the concrete web, high longitudinal tensile stresses occur and lead to transverse cracks. The combined effect of damaged concrete and shear-tension interaction has been addressed in [25] for composite dowels, and earlier in [26-30] regarding headed studs and in [31] in the case of J-hook connectors. In this test, single composite dowels in cracked concrete blocks (crack width $w_{r}=0.5 \mathrm{~mm}$ ) were tested under a load path with a direction of $45^{\circ}$ (shear load $=$ tension load) in addition to pure shear and pure tension loading. The comparison with equivalent tests in uncracked concrete demonstrated that transverse cracks lead to reduced load-bearing capacity of the dowels under combined shear-tension loading, as well as under pure shear or pure tension loading. To further analyse the influence of the cracks and the crack width on the load-bearing capacity of concrete dowels under combined shear-tension loading, more experimental data with varying load direction and crack width is necessary.

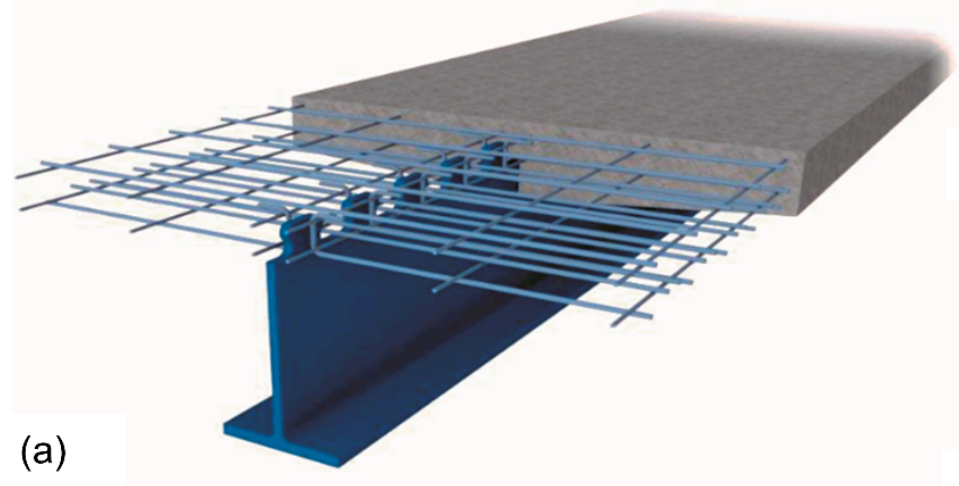

(c)

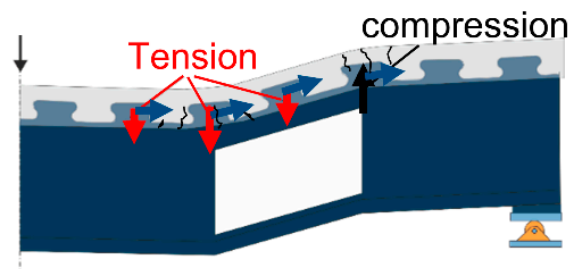

(b)

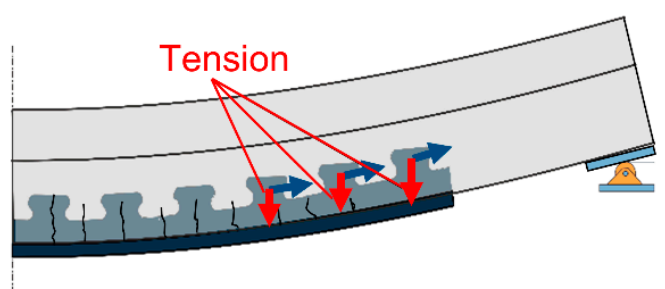

Figure 1. (a) Composite girder with composite dowels; $(\mathbf{b}, \mathbf{c})$ cases with combined shear-tensile loading [18].

\section{Experimental Investigations}

The herein investigated issue, namely, the load-bearing behaviour of composite dowels in cracked concrete subjected to combined shear and tensile loading, mainly concerns building constructions characterized by small concrete covers, for which composite dowels are expected to fail either due to steel failure or due to concrete pry-out. Since steel failure is not influenced by cracks in the concrete, the following experimental program investigates the pry-out failure according to [17].

\subsection{Test Program}

In sum, 32 tests were carried out to examine the load-bearing behaviour of composite dowels in case of damaged concrete for several shear-tension load combinations. Five different load directions $\left(0^{\circ}, 22.5^{\circ}, 45^{\circ}, 67.5^{\circ}, 90^{\circ}\right)$ were considered under different concrete conditions (uncracked concrete, crack widths $0.5 \mathrm{~mm}, 0.8 \mathrm{~mm}$, and $1.0 \mathrm{~mm}$ ). Since the position of the transverse reinforcement within the concrete dowels was found to have a great impact on the load-bearing capacity of the connectors, the clear distance $e_{r}$ between the reinforcement bars and the surface of the steel dowels (Figure 2) was also varied between 0 and $16 \mathrm{~mm}$, but only for undamaged concrete. Table 1 includes the names of the 16 test-series in addition to the load's direction, the crack width and the eccentricity of the dowel reinforcement bars for each series consisting of two identical tests. The IOR 
test series was used to investigate the load-bearing behaviour of the dowels in uncracked concrete while IMR series regarded dowels in cracked concrete.
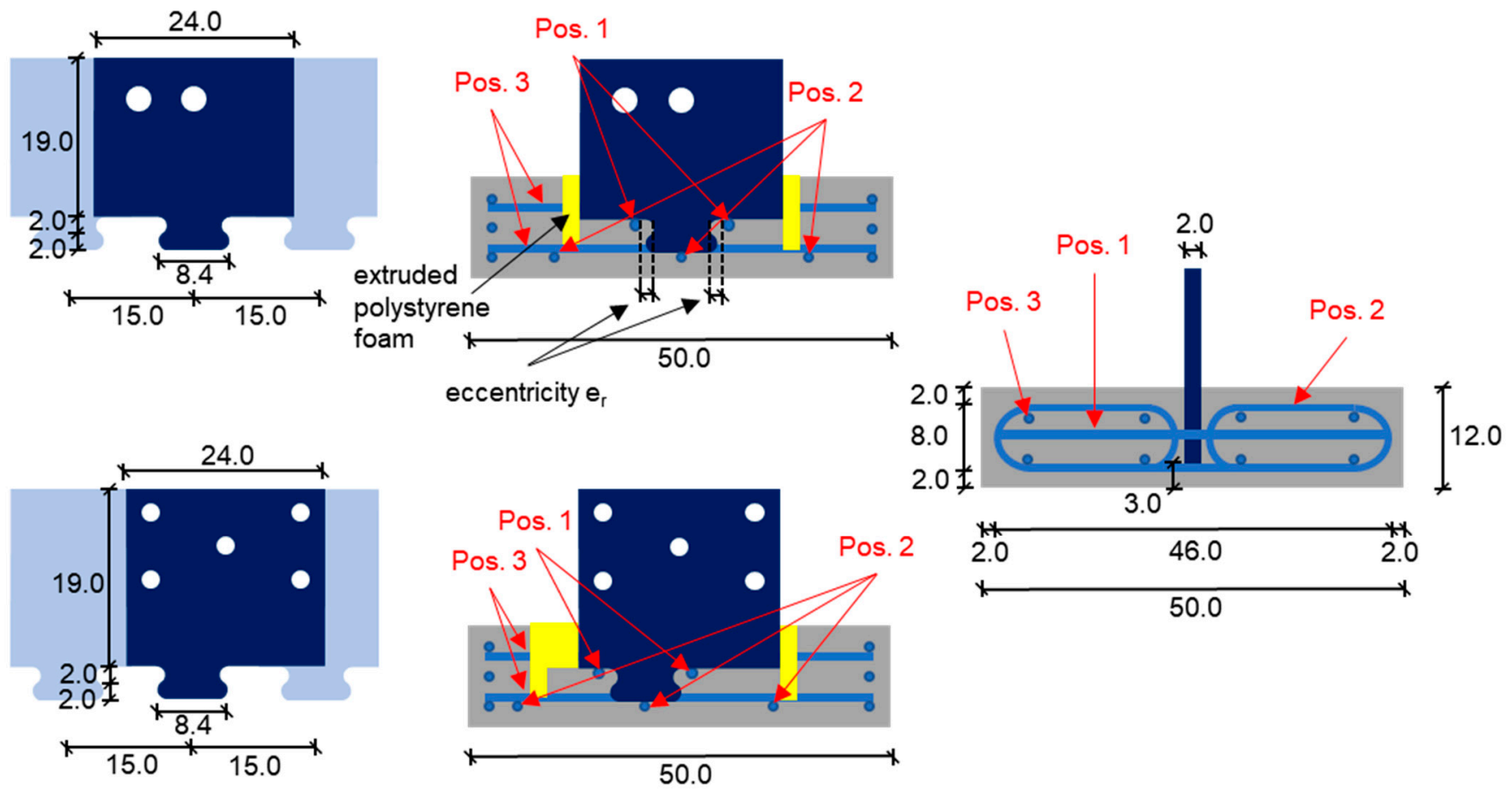

Figure 2. Test specimen of series IOR-x as per [25].

Table 1. Testing program.

\begin{tabular}{|c|c|c|c|c|c|c|c|c|c|c|c|c|c|c|c|c|}
\hline Test & 竎 & $\stackrel{\infty}{\stackrel{\infty}{\sharp}}$ & 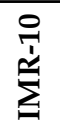 & 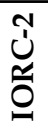 & ֻั & 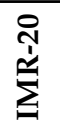 & 茴 & $\begin{array}{l}\stackrel{?}{0} \\
0 \\
0\end{array}$ & 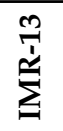 & $\begin{array}{l}\text { 光 } \\
\text { 光 }\end{array}$ & $\frac{+}{\stackrel{1}{\sigma}}$ & 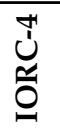 & $\begin{array}{l}\text { Ñ } \\
\stackrel{\text { ڤn}}{\Sigma}\end{array}$ & 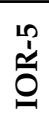 & 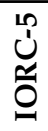 & $\frac{\widehat{N}}{\stackrel{a}{\xi}}$ \\
\hline Angle $\left[^{\circ}\right]$ & & 0 & & & 22.5 & & & & & & & 67.5 & & & 90 & \\
\hline crack width [mm] & 0 & 0.5 & 1.0 & 0 & 0 & 0.5 & 0 & 0 & 0.5 & 0.8 & 0 & 0 & 0.5 & 0 & 0 & 0.5 \\
\hline Eccen-tricity $e_{r}[\mathrm{~mm}]$ & 16 & 16 & 16 & 0 & 16 & 16 & 0 & 16 & 16 & 16 & 0 & 16 & 16 & 0 & 16 & 16 \\
\hline
\end{tabular}

\subsection{Test Specimen}

The test specimens consisted of a single puzzle-shaped steel dowel positioned within normal strength concrete blocks (C30/37) with dimensions and reinforcement as given in Figure 2 (uncracked concrete) and Figure 3 (cracked concrete). Due to the required dense reinforcement necessary for the initiation of the cracks (Figure 4), the maximum aggregate diameter was chosen to $8 \mathrm{~mm}$. The steel dowels' geometry were designed according to [17] and corresponded to a composite dowel bar with a shear connector distance of $e_{x}=150 \mathrm{~mm}$. The steel's strength class was S355 and the web width $t_{w}=20 \mathrm{~mm}$. The concrete cover of the steel dowels was $c_{D, o}=30 \mathrm{~mm}$. The edges of the steel dowels were covered with extruded polystyrene foam to prevent load transfer from the steel webs' edges to the concrete per contact. Furthermore, the lower edge of the foam was at the same level as the lower edge of the steel dowel (Figures 2 and 3) to ensure that the concrete dowels' geometry was similar to that of concrete dowels in a full-scale girder with numerous dowels in a row. The hole pattern in the steel web resulted from the requirements of the test rig in dependence on the load direction. It consisted of two holes for testing with load directions $67.5^{\circ}$ and $90^{\circ}$. Here, the cylinder force was applied directly to the steel web of the dowel. In case of load directions $0^{\circ}, 22.5^{\circ}$, and $45^{\circ}$, the hole pattern consisted of 5 holes as shown in the lower sketches of Figure 2. Here, an additional load distributing steel component was required to 
ensure that the load's line of action ran through the centre of the steel dowel as shown in Figure 5, right. The offset of the steel dowel in relation to the steel web's centre in case of load directions between $0^{\circ}$ and $45^{\circ}$ ensured that the pry-out cone would not reach the edge of the concrete since in case of governing shear forces, the pry-out cone is formed in the direction of the load and not uniformly around the steel dowel.
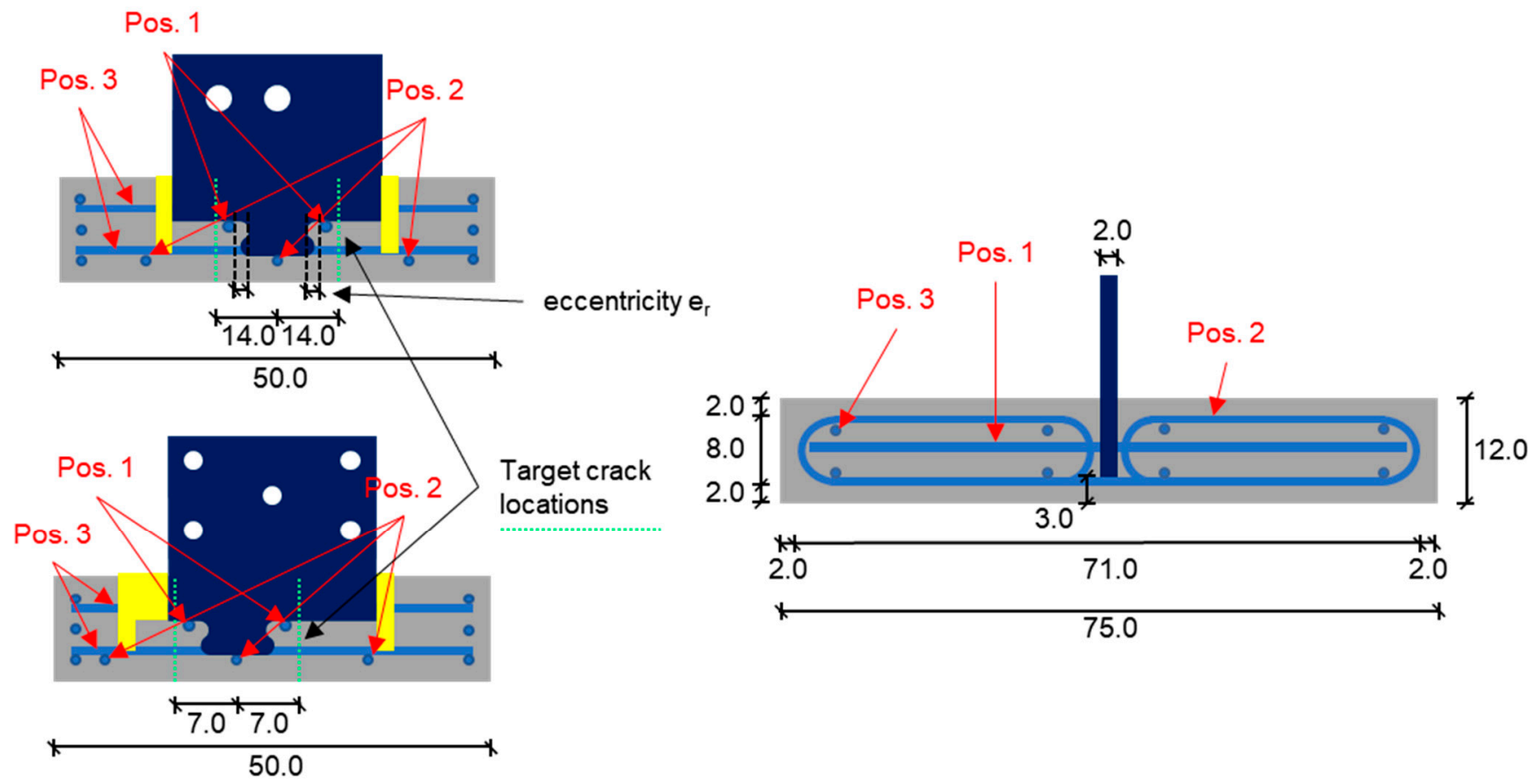

Figure 3. Test specimen of series IMR-x as per [25].
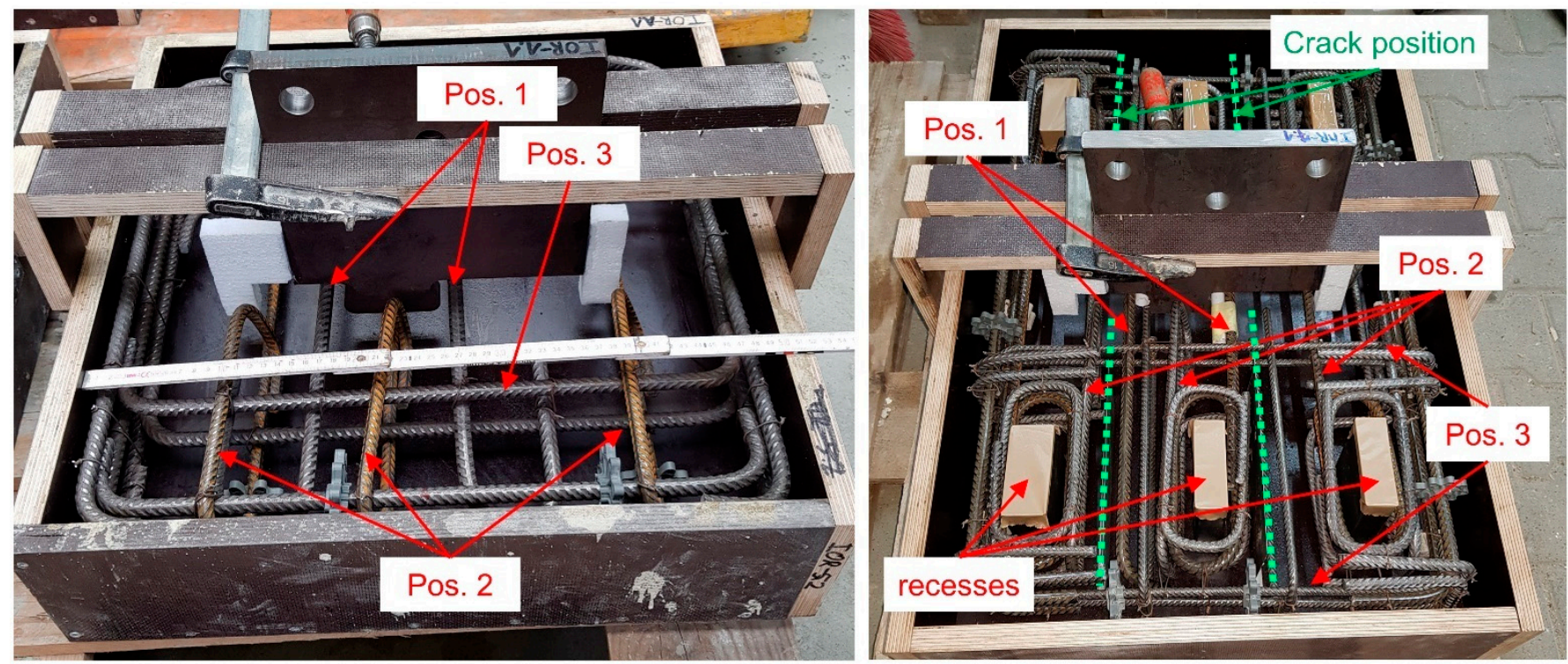

Figure 4. Reinforcement and formwork of series IOR-x and IMR-x.

The reinforcement (high ductile B500B) was identical for all tests regardless of the load direction and the concrete's condition. Transverse reinforcement bars with a diameter of $\varnothing 12 \mathrm{~mm}$ (Figure 2, Pos. 1) were positioned in the steel dowels' recesses. In addition, stirrups were also installed transversely to the steel dowel. For each test specimen, three stirrups with a diameter of $\varnothing 10 \mathrm{~mm}$ were provided at a distance of $\sim 15 \mathrm{~cm}$ (Pos. 2), with the middle stirrup positioned at the axis of the steel dowel. In the direction parallel to the 
composite dowel's axis, eight rebars with a diameter of $\varnothing 12 \mathrm{~mm}$ (Pos. 3) were installed. The concrete cover of the longitudinal reinforcement was $c=30 \mathrm{~mm}$ in both directions. For the test specimens in cracked concrete, further reinforcement was required to ensure that the crack initiation device would not damage the concrete excessively in the region of the load introduction. The additional reinforcement was positioned outside the expected pry-out cone, thus not influencing the load-bearing capacity of the dowels.

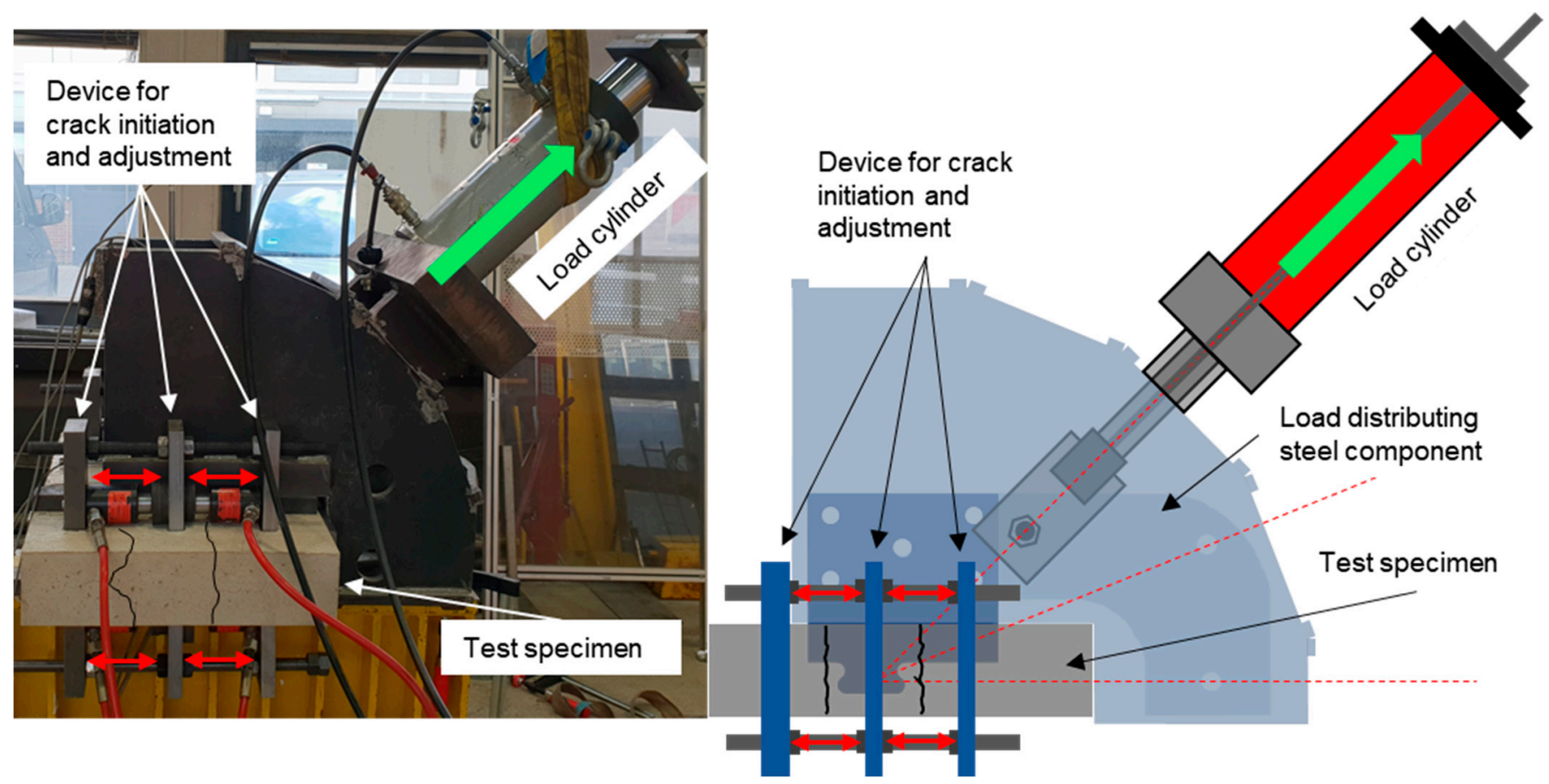

Figure 5. Test setup of tensile-shear tests with a load application angle of $\alpha=45^{\circ}$ with crack initiation and adjustment device.

For the crack initiation, two predetermined crack locations were chosen at a distance of $s_{r}=7 \mathrm{~cm}$ on either side of the steel dowel's centre. In previous research on the influence of the cracks' position [22], the selected crack location proved to be particularly unfavourable, so that the herein executed tests provide "worst-case" results. To control the location of each crack, $0.8 \mathrm{~mm}$ thick steel plates were inserted into the formwork at the desired positions of the cracks. By applying oil onto these plates, adhesion between steel sheet and concrete was eliminated. The device, used for introducing and adjusting the cracks, consisted of massive steel plates positioned into recesses (Figure 4, right) in the concrete blocks. By applying a compressive force between the steel plates in the concrete recesses, the concrete block cracked in the predefined positions (Figure 4 , left).

\subsection{Test Rig, Procedure, and Measurements}

The test rig was developed at the Institute of Structural Concrete at RWTH Aachen University (Figure 5) and consists of a fan-shaped steel frame that allows five loading angles to be applied. In previous research work [19], uncracked test specimens have already been tested with this test rig for the five discussed load directions. In order to investigate the reduction of the load-bearing capacity caused by cracks for different load directions, the test rig was adapted. With the new test rig, cracks can now be introduced in the concrete blocks and adjusted according to the predefined crack widths for all five loading directions prior to loading, while maintaining the initial crack state during the tests' duration.

The required force for the crack initiation was introduced by means of eight smallformat test cylinders, which were inserted between the massive steel plates positioned in the concrete recesses. The crack width could be roughly adjusted by means of the hand 
pump-controlled small-format test cylinders and then fine-adjusted and "locked" using threaded rods (Figure 5, left). A similar method was used in [17] to initiate and adjust the concrete cracks in a controlled manner.

The dowel force was introduced directly into the steel dowel in the cases of $90^{\circ}$ and $67.5^{\circ}$ and via an additional L-shaped steel component for load angles between $0^{\circ}$ and $45^{\circ}$ as shown in Figure 5, right. The additional steel component is necessary so that the line of action of the introduced load crosses the centre of the steel dowel ensuring a momentfree dowel loading. The concrete blocks were supported by the steel fan structure both horizontally and vertically. The same applies to the test cylinder, thus creating a "closed" force system.

The crack widths at both predefined crack locations were continuously measured via eight inductive displacement transducers (IDT) as shown in Figure 6 both during the initiation and adjustment of the cracks and throughout the test procedure. For each of the two cracks, IDTs were positioned to the left and right of the dowel bar both at the top and bottom of the specimen. In addition, IDTs were used to measure both the horizontal and vertical slip of the steel dowel. Finally, a load cell was used to record the applied force.
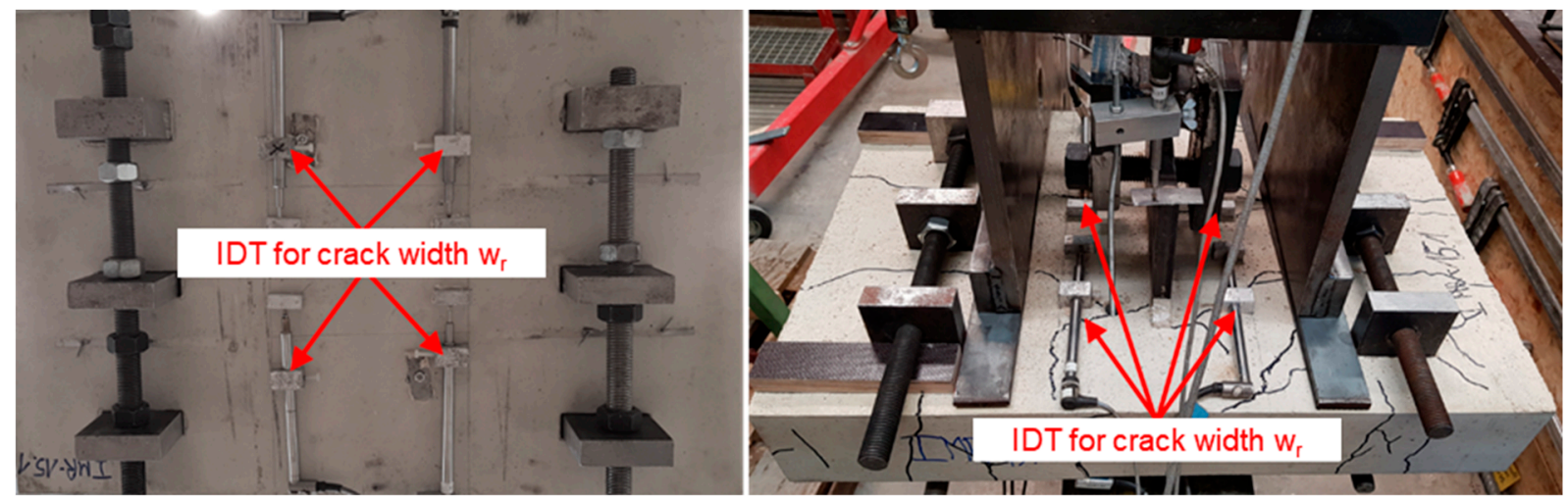

Figure 6. Inductive displacement transducers (IDT) for the measurement of the crack widths.

\subsection{Test Results}

The load-bearing capacity of the tested dowels $P_{\max }$ decreased with increasing crack width as well as with increasing load application angle (increasing tensile component). Table 2 summarizes the test results. In addition to the load angle and predefined crack width $w_{r}$, material properties of the concrete such as compressive strength from cube specimens $f_{c m, c u b e}$, the modulus of elasticity $E_{c m}$, and the average concrete tensile strength $f_{c t, m}$ are given. Furthermore, the displacement of the steel dowel in the direction of the force when the maximum load is reached $\delta_{\max }$ is given in addition to the ductility $\delta_{u}$ of the specimens (according to [32]). Moreover, the load-bearing capacity $P_{\max }$ and the components of the maximum force in horizontal $P_{H, \max }$ and vertical $P_{V, \max }$ directions are listed. Last but not least, the failure mode is included, which was identified as either a pry-out or a pull-out failure.

In undamaged concrete and in the cases of $0^{\circ}$ and $22.5^{\circ}$, the eccentricity of the concrete dowel's reinforcement bars $e_{r}$ did not influence the failure mode (pry-out failure for all specimens). A pry-out cone could not be activated in case of a higher tensile load component, namely for load angle $\geq 45^{\circ}$. Here, the position of the dowel reinforcement significantly influenced the load-bearing capacity and failure mode of the connectors. Since the dowels shape for the herein considered puzzle form (PZ) does not provide a sufficient anchoring effect in the concrete, the concrete in the recesses of the steel dowel failed leading to the steel dowel being pulled out of the concrete at relatively low tensile loads. This effect is demonstrated in Figure 7 where the specimens IOR-1.1 (pure shear loading and eccentricity $\left.e_{r}=16 \mathrm{~mm}\right)$, IOR-3.2 ( $45^{\circ}$ load direction and eccentricity $\left.e_{r}=0 \mathrm{~mm}\right)$, and IORC $-3.2\left(45^{\circ}\right.$ load direction and eccentricity $e_{r}=16 \mathrm{~mm}$ ) are displayed in top view and in saw cuts after failure. 
Table 2. Test results.

\begin{tabular}{|c|c|c|c|c|c|c|c|c|c|c|c|}
\hline \multirow[b]{2}{*}{ Name } & \multicolumn{2}{|c|}{ Parameters } & \multicolumn{3}{|c|}{ Material Properties } & \multicolumn{2}{|c|}{ Slip } & \multicolumn{3}{|c|}{ Load-Bearing Capacity } & \multirow[b]{2}{*}{$\begin{array}{c}\text { Failure } \\
\text { Mode } \\
* *\end{array}$} \\
\hline & $\begin{array}{l}\frac{\sigma}{0} \\
\frac{0}{00} \\
\Xi\end{array}$ & $\begin{array}{c}\text { Crack } \\
\text { Width } w_{r} \\
\text { [mm] }\end{array}$ & $\begin{array}{c}\text { Cube } \\
\text { Strength } \\
f_{c m, c u b e} \\
{\left[\mathrm{~N} / \mathrm{mm}^{2}\right]}\end{array}$ & $\begin{array}{c}\text { Elasticity } \\
\text { Modulus } \\
E_{c m} * \\
{\left[\mathrm{~N} / \mathrm{mm}^{2}\right]}\end{array}$ & $\begin{array}{c}\text { Tensile } \\
\text { Strength } \\
f_{c t, m} \\
{\left[\mathrm{~N} / \mathrm{mm}^{2}\right]}\end{array}$ & $\begin{array}{c}\delta_{\max } \\
{[\mathrm{mm}]}\end{array}$ & $\begin{array}{c}\delta_{u} \\
{[\mathrm{~mm}]}\end{array}$ & $\begin{array}{l}P_{\max } \\
{[\mathbf{k N}]}\end{array}$ & $\begin{array}{c}P_{H, \max } \\
{[\mathrm{kN}]}\end{array}$ & $\begin{array}{c}P_{V, \max } \\
{[\mathbf{k N}]}\end{array}$ & \\
\hline IOR 1.1 & \multirow{6}{*}{0} & 0.00 & 42.3 & 24,400 & 2.9 & 6.1 & 7.6 & 186 & 186 & 0 & p-o-t\&b \\
\hline IOR 1.2 & & 0.00 & 42.3 & 24,400 & 2.9 & 4.2 & 6.4 & 164 & 164 & 0 & p-o-t\&b \\
\hline IMR 8.1 & & 0.50 & 47.1 & 27,100 & 2.9 & 4,2 & 13,8 & 114 & 114 & 0 & $\mathrm{p}-\mathrm{o}-\mathrm{b}$ \\
\hline IMR 8.2 & & 0.50 & 47.1 & 27,100 & 2.9 & 10,2 & 19,3 & 143 & 143 & 0 & $p-o-b$ \\
\hline IMR 10.1 & & 1.00 & 47.1 & 27,100 & 2.9 & 2.7 & 8.2 & 118 & 118 & 0 & $\mathrm{p}-\mathrm{o}-\mathrm{b}$ \\
\hline IMR 10.2 & & 1.00 & 47.1 & 27,100 & 2.9 & 2.7 & 14.1 & 104 & 104 & 0 & p-o-b \\
\hline IORC 2.1 & \multirow{6}{*}{22.5} & 0.00 & 44.6 & 21,900 & 2.8 & 3.3 & 3.4 & 132 & 122 & 51 & p-o-t \\
\hline IORC 2.2 & & 0.00 & 44.6 & 21,900 & 2.8 & 2.2 & 2.5 & 136 & 125 & 52 & $\mathrm{p}-\mathrm{o}-\mathrm{t}$ \\
\hline IOR 2.1 & & 0.00 & 42.3 & 24,400 & 2.9 & 3.9 & 4.8 & 129 & 119 & 49 & p-o-t \\
\hline IOR 2.2 & & 0.00 & 42.3 & 24,400 & 2.9 & 5.4 & 8.6 & 122 & 113 & 47 & p-o-t \\
\hline IMR 20.1 & & 0.50 & 44.3 & 22,700 & 2.8 & 6.2 & 10.9 & 94 & 87 & 36 & pull-o \\
\hline IMR 20.2 & & 0.50 & 44.3 & 22,700 & 2.8 & 2.9 & 4.5 & 115 & 106 & 44 & pull-o \\
\hline IOR 3.1 & \multirow{8}{*}{45} & 0.00 & 42.3 & 24,400 & 2.9 & 2.8 & 4.3 & 90 & 64 & 64 & p-o-t \\
\hline IOR 3.2 & & 0.00 & 42.3 & 24,400 & 2.9 & 2.8 & 3.9 & 95 & 67 & 67 & $\mathrm{p}-\mathrm{o}-\mathrm{t}$ \\
\hline IORC 3.1 & & 0.00 & 44.6 & 21,900 & 2.8 & 2.6 & 3.7 & 68 & 48 & 48 & pull-o \\
\hline IORC 3.2 & & 0.00 & 44.6 & 21,900 & 2.8 & 1.3 & 3.3 & 58 & 41 & 41 & pull-o \\
\hline IMR 13.1 & & 0.50 & 46.1 & 24,100 & 2.5 & 1.4 & 2.2 & 54 & 38 & 38 & pull-o \\
\hline IMR 13.2 & & 0.50 & 46.1 & 24,100 & 2.5 & 2.1 & 3.1 & 50 & 35 & 35 & pull-o \\
\hline IMR 21.1 & & 0.80 & 44.3 & 22,700 & 2.8 & 3.2 & 4.3 & 51 & 36 & 36 & pull-o \\
\hline IMR 21.2 & & 0.80 & 44.3 & 22,700 & 2.8 & 2.7 & 3.9 & 56 & 40 & 40 & pull-o \\
\hline IOR 4.1 & \multirow{6}{*}{67.5} & 0.00 & 42.3 & 24,400 & 2.9 & 3.9 & 4.8 & 75 & 29 & 69 & p-o-t \\
\hline IOR 4.2 & & 0.00 & 42.3 & 24,400 & 2.9 & 3.6 & 5.5 & 73 & 28 & 67 & $\mathrm{p}-\mathrm{o}-\mathrm{t}$ \\
\hline IORC 4.1 & & 0.00 & 44.6 & 21,200 & 2.8 & 1.6 & 2.8 & 51 & 19 & 47 & pull-o \\
\hline IORC 4.2 & & 0.00 & 44.6 & 21,200 & 2.8 & 3.0 & 3.9 & 56 & 22 & 52 & pull-o \\
\hline IMR 22.1 & & 0.50 & 44.3 & 22,700 & 2.8 & 3.7 & 4.9 & 38 & 15 & 35 & pull-o \\
\hline IMR 22.2 & & 0.50 & 44.3 & 22,700 & 2.8 & 4.1 & 6.8 & 54 & 21 & 50 & p-o-t \\
\hline IOR 5.1 & \multirow{6}{*}{90} & 0.00 & 42.3 & 24,400 & 2.9 & 3.2 & 4.6 & 65 & 0 & 65 & p-o-t \\
\hline IOR 5.2 & & 0.00 & 42.3 & 24,400 & 2.9 & 2.2 & 3.6 & 66 & 0 & 66 & $\mathrm{p}-\mathrm{o}-\mathrm{t}$ \\
\hline IORC 5.1 & & 0.00 & 44.6 & 21,200 & 2.8 & 0.8 & 1.1 & 48 & 0 & 48 & pull-o \\
\hline IORC 5.2 & & 0.00 & 44.6 & 21,200 & 2.8 & 0.6 & 1.2 & 40 & 0 & 40 & pull-o \\
\hline IMR 17.1 & & 0.50 & 46.1 & 24,100 & 2.5 & 1.4 & 2.2 & 38 & 0 & 38 & pull-o \\
\hline IMR 17.2 & & 0.50 & 46.1 & 24,100 & 2.5 & 1.4 & 4.1 & 38 & 0 & 38 & pull-o \\
\hline
\end{tabular}



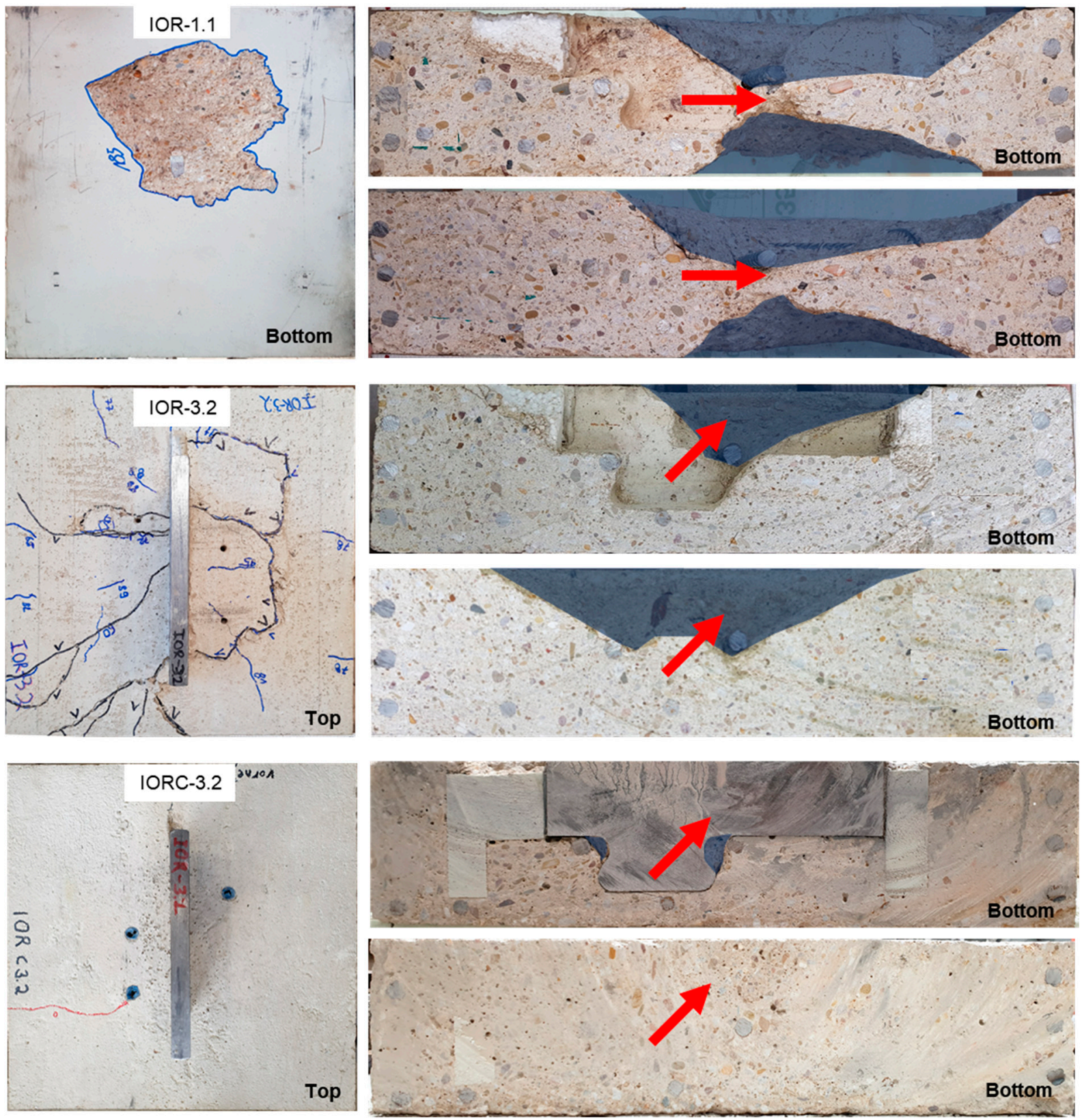

Figure 7. Overview of the failure modes (IOR-x, uncracked concrete).

While in the cases of IOR-1.1 and IOR-3.2, pry-out failure occurred, IORC-3.2 exhibited pull-out failure. In case of pure shear loading, pull-out failure is not possible since a considerable force in the direction perpendicular to axis of the composite dowel bar is necessary. With rising tensile loading, it becomes increasingly important for the concrete dowel's reinforcement to be positioned closer to-or even within-the steel dowel's recess $\left(e_{r}<16 \mathrm{~mm}\right)$ in order to contribute against pull-out failure as a further anchoring component. Dowel reinforcement bars positioned outside the steel dowel's recess $\left(e_{r} \geq 16 \mathrm{~mm}\right)$ lead to a concrete crack starting from the steel dowel's "nose" and continuously growing in front of the reinforcement bars. Thus, the reinforcement cannot be activated as an additional load distributing and load anchoring component (saw-cut of IORC-3.2 in Figure 7).The same applies for dowels in damaged concrete. The tensile force led to transverse cracks which influenced the load-bearing behaviour of the specimens. The tensile stresses in the concrete affect the dowels' load-bearing capacity due to the resulting cracks separating the pry-out cone into several smaller segments (Figure 8, IMR-8.2). Additionally, these tensile 
stresses lead to a degradation of the anchoring effect of the steel dowel in the concrete. This effect can be identified by comparing series IORC-4 with IMR-22 or IORC-5 with IMR-17 in Table 2. The two pairs consist of test specimens with identical load direction and dowel reinforcement eccentricity. In both cases the concrete's condition is varied, which was undamaged in case of IORC-x, and damaged by means of approx. $0.5 \mathrm{~mm}$ wide cracks in case of IMR-x (Table 2). While all specimens failed due to the steel dowel being pulled out of the concrete, the mean load-bearing capacity was lower in the cracked concrete. Additionally, IMR-20 was the only test series with a load direction of $22.5^{\circ}$ in which pull-out failure occurred (Figure 8, IMR-20.2). This indicates that the anchoring effect of the steel dowels was sufficient in case of IOR-2 (22.5 ; undamaged concrete, $\left.e_{r}=16 \mathrm{~mm}\right)$ but not in case of IMR-20 $\left(22.5^{\circ}, w_{r}=0.5 \mathrm{~mm}, e_{r}=16 \mathrm{~mm}\right)$. The tensile force leading to the transverse cracks in the concrete reduced the anchoring capability of the steel dowel in the concrete and led to pull-out failure at lower load levels.
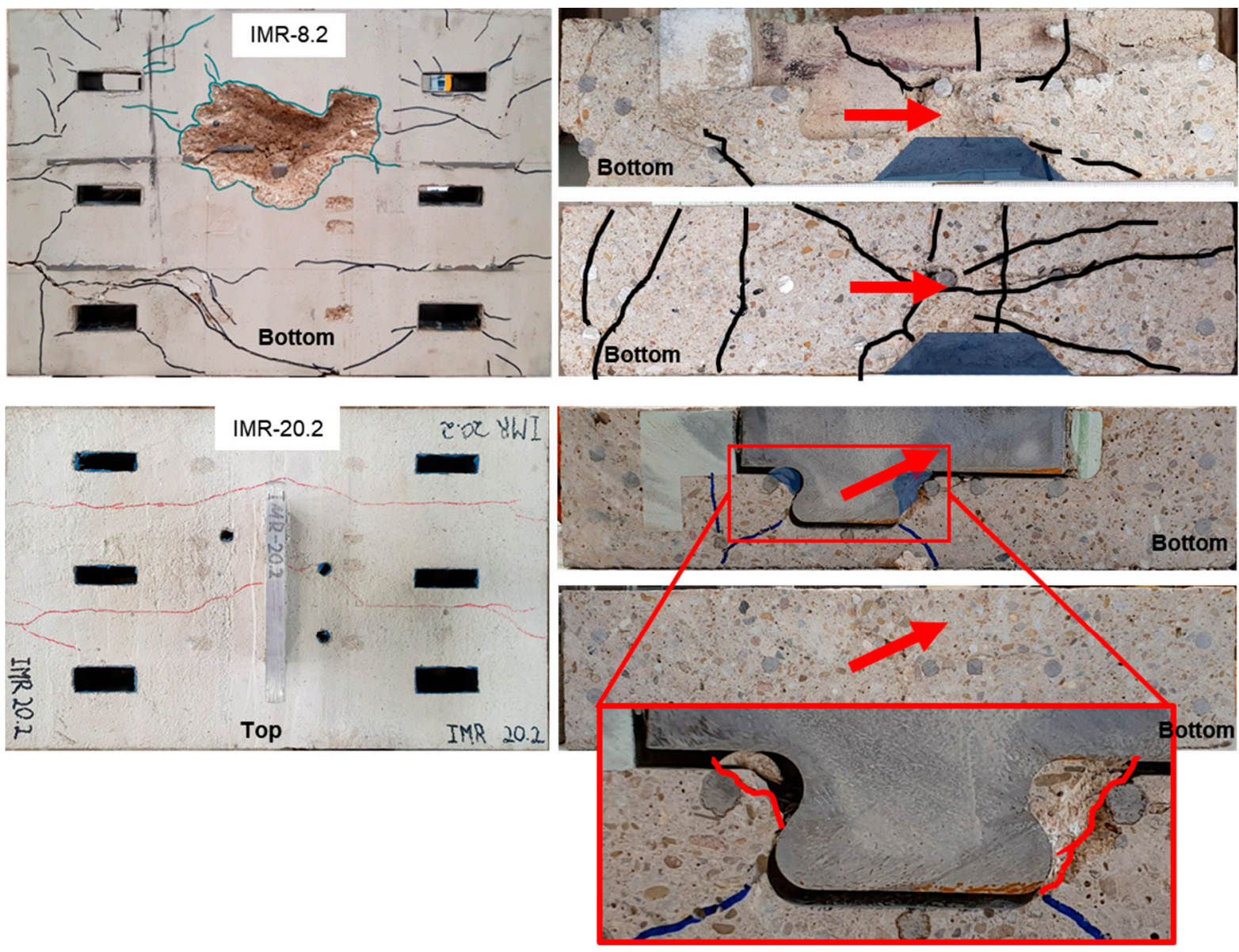

Figure 8. Overview of the failure modes (IMR-x, cracked concrete).

Figure 9 includes an overview of all results. Diagram (a) contains only specimens in uncracked concrete with varying concrete dowel reinforcement eccentricity $e_{r}$ between 0 and $16 \mathrm{~mm}$. As long as the unfavourable pull-out failure is avoided and pry-out failure occurs, the maximum force reached lied within the range defined by the shear and tensile load-bearing capacity. Pry-out failure can be assumed to be the decisive failure mode regardless of the load direction as long as the reinforcement bar in the concrete dowel remains within the steel dowels' recess as demonstrated in diagram (a), $e_{r}=0 \mathrm{~mm}$. This favourable position of the reinforcement bars is presented in the lower part of Figure 9 , red. If the reinforcement bars in the concrete dowel are positioned outside the steel dowel's recess, pull-out failure becomes decisive as soon as a significant tensile force is applied 
(load direction $\geq 22.5^{\circ}$ ) and occurs at a constant tensile force plateau as demonstrated in Figure 9, diagram a). The load-bearing capacity of the dowels in case of pull-out failure is approx. $46 \mathrm{kN}$. For shear-tension interaction and concrete dowel reinforcement positioned outside the steel dowel's recess, pull-out occurs as soon as the force's tensile component reaches this upper limit.
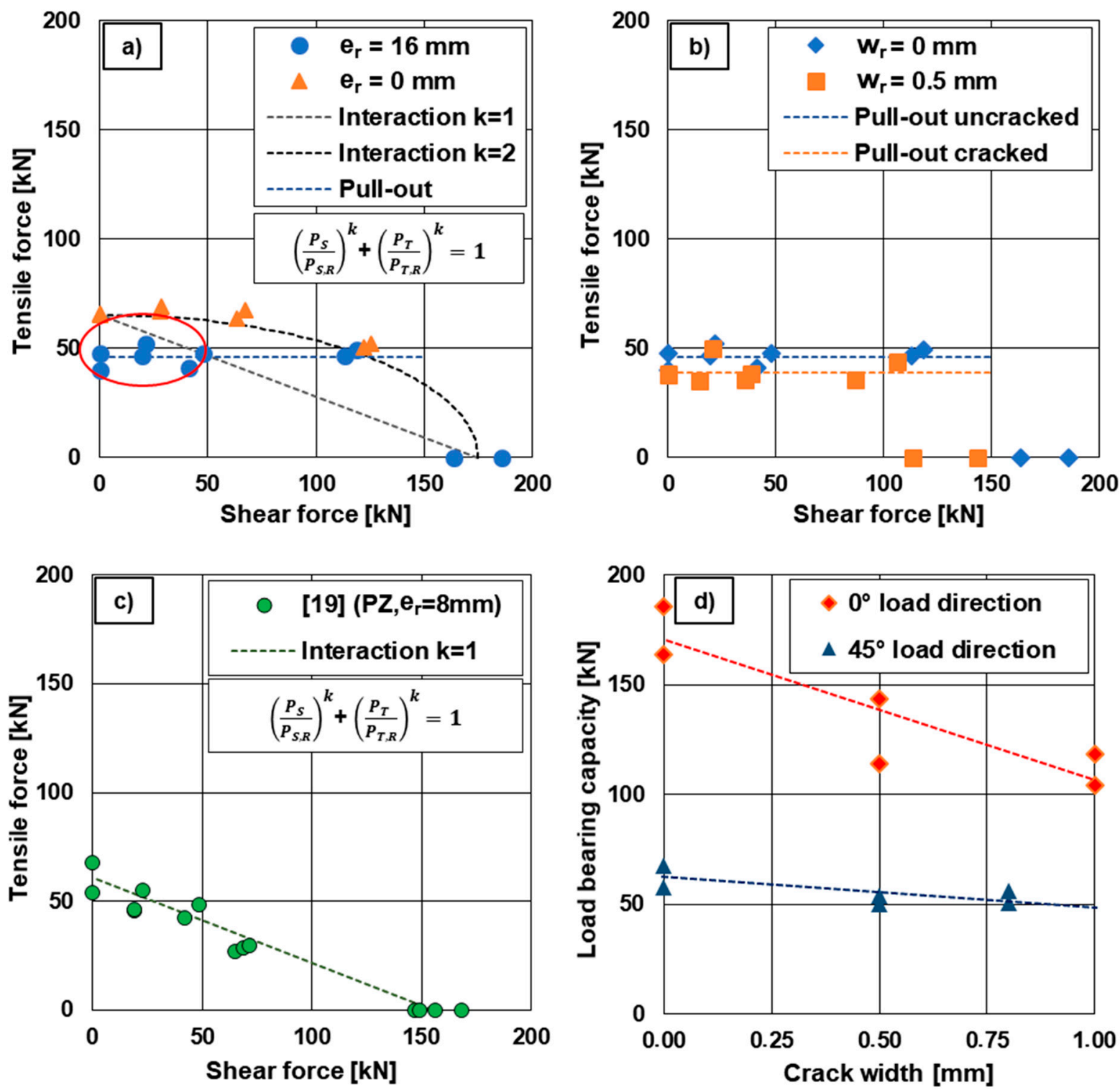

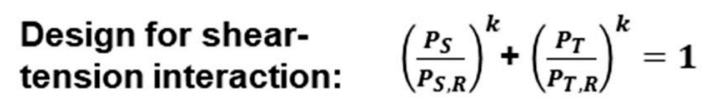

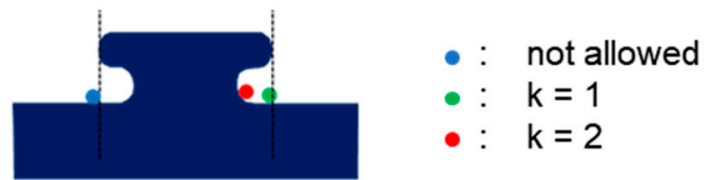

Figure 9. Results overview and design approach: (a) influence of reinforcement eccentricity $e_{r}$ and (b) of the concrete's condition on the shear-tensile interaction; (c) linear shear-tensile-interaction curve in case of reinforcement eccentricity $e_{r}=8 \mathrm{~mm}$; (d) influence of crack width on load bearing capacity.

The interaction of the tensile and shear forces can be considered using Equation (1). Here, the combined acting shear and tensile loads $\left(P_{S}\right.$ and $\left.P_{T}\right)$ are related to their associated ultimate load-bearing capacities in case of concrete pry-out failure $\left(P_{S, R}\right.$ and $\left.P_{T, R}\right)$. The load-bearing capacity, both for tensile and shear loading, shall be calculated by means of valid regulations, currently [17]. The form of the interaction's relationship can be specified 
by the exponent $k$. In previous research, limits 1 and 2 have been proposed for the choice of $k$, while the exact value should be calculated in dependence on the position and amount of the concrete dowel's reinforcement. According to the findings presented here, since the exact position of the reinforcement bars is difficult to set on the construction site a simpler approach is suggested.

$$
\left(\frac{P_{S}}{P_{S, R}}\right)^{k}+\left(\frac{P_{T}}{P_{T, R}}\right)^{k} \leq 1.0
$$

While in case of $e_{r}=0 \mathrm{~mm}$, with ensured pry-out failure regardless of the load's direction, a quadratic interaction formula can be applied to the design, pull-out is characterized by premature failure at load levels below the linear interaction between tensile and shear load-bearing capacity. This is demonstrated in diagram (a), red ellipse. Diagram (b) includes specimens with $e_{r}=16 \mathrm{~mm}$ in both uncracked and cracked concrete. On axis X, the reduction of the pure shear load-bearing capacity can be identified in case of pry-out failure owing to the cracks separating the pry-out cone into several smaller segments. The degradation of the concrete's condition leads to a reduction of the load-bearing capacity by approx. $26 \%$. Since for load directions above $22.5^{\circ}$ solely pull-out failure occurred, it is not possible to identify the effect of cracks in the concrete in case of pry-out failure. Nevertheless, the load-bearing capacity of the specimens was also slightly lower in cracked concrete for pull-out failure as demonstrated in diagram by the blue and orange dotted lines.

Diagram (c) contains results from CLASSEN ([19]). The latter demonstrates the validity of the linear interaction between the pure shear and the pure tensile load-bearing capacity when positioning the concrete dowel reinforcement bars within the steel dowels' recess without securing the bars directly at the steel surface $\left(0 \mathrm{~mm}<e_{r}=8 \mathrm{~mm}\right)$. Finally, diagram (d) includes results of varying crack width for the load directions $0^{\circ}$ and $45^{\circ}$. For pure shear loading, pry-out failure was decisive and the load-bearing capacity was reduced with increasing crack width as demonstrated earlier in [22,33]. For a load direction of $45^{\circ}$ only pull-out failure was observed. Here, the concrete's condition only influences the loadbearing capacity marginally. While the pry-out cone is separated by the cracks, thus leading to a reduced concrete surface available for the tensile load transfer, the mechanisms of the load reduction are different in case of pull-out failure. Here, the load-bearing capacity is influenced negatively by the tensile stresses in the concrete required for the crack initiation and not by the resulting cracks. The anchoring effect of the steel dowel in the concrete is decreased as the concrete within the steel dowel's recesses is being "pulled-out" by the forces necessary to create the cracks.

While tensile forces in the composite dowels should be avoided in case of puzzleshaped connectors, securing the reinforcement bars of the concrete dowels at the surface of the steel dowel's recesses leads to good load-bearing behaviour (avoidance of pull-out failure) and sufficient resistance against tensile loading. The shear-tension interaction Formula (1) may then be used with the value $k=2$ for the exponent. While a value of $k=1$ can be used in case of the bars being positioned within the steel dowel's recesses without touching the steel dowel's surface $\left(e_{r}>0 \mathrm{~mm}\right)$, it is difficult to secure such conditions on construction sites. Additionally, the effort required for securing $e_{r}=0 \mathrm{~mm}$ would only be marginally higher. Thus, it is suggested to consider the latter $\left(e_{r}=0 \mathrm{~mm}\right)$ as soon as tensile loading is expected on the dowels.

Better suited dowel shapes with bigger steel recesses and thus better anchoring capabilities (such as the clothoid-shaped dowels (CL)) should be preferred as soon as tensile loads are expected by design.

\section{Conclusions}

- The load-bearing behaviour of single puzzle-shaped composite dowels was investigated for several load directions in undamaged and damaged (cracked) concrete by means of 32 tests.

- Concrete damage in terms of transverse cracks is proven to reduce the dowels' loadbearing capacity. 
- $\quad$ Pry-out failure is significantly impacted by wide cracks in the concrete regardless of the load's direction.

- In the case of significant tensile loading, pry-out failure was not achieved within the presented test program since the dowels were prematurely pulled-out of the concrete. Nevertheless, the cracks and the crack-inducing stresses in the concrete impacted negatively the load-bearing capacity of the dowels, even in the case of pull-out failure.

- The unfavourable pull-out failure can be avoided by placing the dowel reinforcement as close as possible to the steel dowels, preferably within the steel dowels' recesses.

- Securing the reinforcement bars at the steel dowels' surface, for example, by tying the two bars in the front and back of each steel dowel together, leads to the best possible load-bearing behaviour, since the reinforcement can then contribute to the anchoring of the steel dowels and to the load distribution within the concrete.

- Depending on the position of the dowel reinforcement bars, two design modes were defined regarding shear-tension interaction.

- A quadratic interaction between pure shear and pure tensile load-bearing capacity shall be considered in the case of the dowel reinforcement being secured at the steel dowels' surface.

- A less favourable design, namely, a linear interaction, may be considered if the dowel reinforcement is positioned within the steel dowels' recesses without being secured at the steel dowels' surface.

- In the case of cracked concrete, the defined shear-tension interaction curves (quadratic and linear) may be used by considering the reduced load-bearing capacity of the dowels in cracked concrete under pure shear and pure tensile loading.

\section{Outlook}

While important conclusions could be derived from the presented experimental investigations, some matters remain unsolved. Further shear-tension interaction tests are necessary with lower reinforcement eccentricity $e_{r}$ to examine the effects of concrete cracks on the load-bearing behaviour of the dowels in case of pry-out failure. Additionally, other dowel shapes with better anchoring properties should be considered. The investigated PZ-shape is characterized by very small recesses in contrast to the CL- and PZT-shape thus providing conservative results. Finally, full-scale beam tests should be conducted, in which realistic loading conditions can be considered.

Author Contributions: Conceptualization, G.C. and J.H.; methodology, G.C. and M.C.; investigation, G.C.; resources, J.H.; data curation, G.C.; writing-original draft preparation, G.C.; writing—review and editing, K.W. and J.U.; visualization, G.C.; supervision, J.H. and M.C.; project administration, J.H.; funding acquisition, J.H. and M.C. All authors have read and agreed to the published version of the manuscript.

Funding: The presented investigations have been achieved within a research project, which has been gratefully funded by the German Federal Ministry for Economic Affairs and Energy (BMWi) via the German Federation of Industrial Research Associations "Otto von Guericke" e.V. (AiF) within the framework of the program for the promotion of joint industrial research (IGF-No. 19438 N) on the basis of a resolution of the German Bundestag. The authors would like to thank the BMWi for the financial support and FOSTA for their organizational support.

Data Availability Statement: A comprehensive summery of all results can be found in https:/ / shop.s tahldaten.de/produkt/p-1208-konsistentes-bemessungsmodell-fuer-fertigungsoptimierte-verbundd uebelleisten-grundlagen-fuer-dast-richtlinie-und-ueberfuehrung-in-eurocode-4, accessed on 24 December 2021.

Conflicts of Interest: The authors declare no conflict of interest. The funders had no role in the design of the study; in the collection, analyses, or interpretation of data; in the writing of the manuscript, or in the decision to publish the results. 


\section{References}

1. Feldmann, M.; Wolters, K.; Hegger, J.; Claßen, M.; Christou, G.; Kurz, W.; Broschart, Y. Konsistentes Bemessungsmodell für Fertigungsoptimierte Verbunddübelleisten: Abschlussbericht P 1208; Forschungsvereinigung Stahlanwendung e. V. (FOSTA): Dusseldorf, Germany, 2021.

2. Broschart, Y.; Kurz, W.; Wolters, K.; Christou, G.; Feldmann, M.; Hegger, J.; Claßen, M. Developement of a consistent design concept for composite dowels. In Proceedings of the 9th International Conference of Composite Construction in Steel and Concrete, Stromberg, Germany, 26-30 July 2021.

3. Christou, G.; Wolters, K.; Broschart, Y.; Hegger, J.; Feldmann, M.; Kurz, W.; Claßen, M. Entwicklung eines konsistenten Bemessungsmodells für Verbunddübelleisten/Development of a consistent design concept for composite dowels. Bauingenieur 2021, 96, 212-223. [CrossRef]

4. Kopp, M.; Christou, G.; Stark, A.; Hegger, J.; Feldmann, M. Integriertes Deckensystem für den Stahl- und Verbundbau. Stahlbau 2018, 87, 136-148. [CrossRef]

5. Broschart, Y.; Kurz, W.; Wolters, K.; Christou, G.; Claßen, M. Influencing Parameters on the Load-bearing Capacity of Composite Dowels positioned close to the free Surface of Concrete Slabs. In Nordic Steel 2019, Proceedings of the Fourteenth Nordic Steel Construction Conference 2019, Copenhagen, Denmark, 18-20 September 2019; Jönsson, J., Ed.; Ernst \& Sohn: Berlin, Germany, 2019; pp. 295-300.

6. Hegger, J.; Claßen, M.; Schaumann, P.; Sothmann, J.; Feldmann, M.; Döring, B. Entwicklung einer integrierten Verbunddecke für nachhaltige Stahlbauten. Stahlbau 2013, 82, 11-17. [CrossRef]

7. Berthellemy, J.; Lorenc, W.; Mensinger, M.; Ndogmo, J.; Seidl, G. Zum Tragverhalten von Verbunddübeln-Teil 2: Ermüdungsverhalten. Stahlbau 2011, 80, 256-267. [CrossRef]

8. Harnatkiewicz, P.; Kopczyński, A.; Kożuch, M.; Lorenc, W.; Rowiński, S. Research on fatigue cracks in composite dowel shear connection. Eng. Fail. Anal. 2011, 18, 1279-1294. [CrossRef]

9. Dudzinski, W.; Pekalski, G.; Harnatkiewicz, P.; Kopczynski, A.; Lorenc, W.; Kożuch, M.; Rowiński, S. Study on fatigue cracks in steel-concrete shear connection with composite dowels. Arch. Civ. Mech. Eng. 2011, 11, 839-858. [CrossRef]

10. Seidl, G.; Stambuk, M.; Lorenc, W.; Kołakowski, T.; Petzek, E. Wirtschaftliche Verbundbauweisen im Brückenbau-Bauweisen mit Verbunddübelleisten. Stahlbau 2013, 82, 510-521. [CrossRef]

11. Christou, G.; Hegger, J.; Classen, M. Fatigue of clothoid shaped rib shear connectors. J. Constr. Steel Res. 2020, 171, 106-133. [CrossRef]

12. Christou, G.; Ungermann, J.; Wolters, K.; Hegger, J.; Claßen, M. Ermüdung von Verbunddübelleisten-Experimentelle Untersuchungen. Stahlbau 2020, 89, 388-398. [CrossRef]

13. Christou, G.; Ungermann, J.; Wolters, K.; Hegger, J.; Claßen, M. Ermüdung von Verbunddübelleisten. Beton-Und. Stahlbetonbau 2020, 115, 355-363. [CrossRef]

14. Wolters, K.; Christou, G.; Feldmann, M. Untersuchungen zum Risswachstum in Verbunddübelleisten. Bauingenieur 2019, 94, 216-227. [CrossRef]

15. Christou, G.; Schmidt, C.; Hegger, J.; Classen, M. The effect of concrete fatigue on the cyclic behaviour of composite dowelsDerivation of a design approach based on experimental findings. Eng. Struct. 2022, 253, 113743. [CrossRef]

16. Gallwoszus, J.; Claßen, M.; Hartje, J. Ermüdung von Verbundkonstruktionen mit Verbunddübelleisten (lokales Tragverhalten). BuSt 2015, 110, 382-393. [CrossRef]

17. Deutsches Institut für Bautechnik. Stahlverbundträger mit Verbunddübelleisten in Klothoiden-und Puzzleform: Allgemeine Bauartgenehmigung Z-26.4-56; Forschungsvereinigung Stahlanwendung e. V. (FOSTA): Berlin, Germany, 2018.

18. Claßen, M.; Adam, V.; Kueres, D.; Hegger, J. Zug-Schub-Interaktion von puzzleförmigen Verbunddübelleisten. BuSt 2017, 112, 334-345. [CrossRef]

19. Classen, M.; Herbrand, M.; Adam, V.; Kueres, D.; Sarac, M. Puzzle-shaped rib shear connectors subjected to combined shear and tension. J. Constr. Steel Res. 2018, 145, 232-243. [CrossRef]

20. Claßen, M.; Hegger, J. Verankerungsverhalten von Verbunddübelleisten in schlanken Betongurten. Bautechnik 2014, 91, 869-883. [CrossRef]

21. Claßen, M.; Hegger, J. Ausstanzmodell mit Rissreibung für Verbunddübelleisten im gerissenen Beton. BuSt 2017, 112, 155-166. [CrossRef]

22. Classen, M.; Hegger, J. Shear Tests on Composite Dowel Rib Connectors in Cracked Concrete. ACI SJ 2018, 115, 661-671. [CrossRef]

23. Claßen, M.; Hegger, J. Assessing the pry-out resistance of open rib shear connectors in cracked concrete-Engineering model with aggregate interlock. Eng. Struct. 2017, 148, 254-262. [CrossRef]

24. Classen, M.; Dressen, T. Experimental Investigations on Prestressed Concrete Beams with Openings. ACI SJ 2015, 112, 221-232. [CrossRef]

25. Christou, G.; Wolters, K.; Broschart, Y. Verbunddübelleisten unter kombinierter Schub-Zug-Beanspruchung im gerissenen Beton. Bauingenieur 2019, 94, 228-236. [CrossRef]

26. McMackin, P.J.; Slutter, R.G.; Fisher, J.W. Headed Steel Anchor under Combined Loading. AISC Eng. J. 1973, 10, 43-52.

27. Lin, Z.F.; Liu, Y.Q. Model Experiment on Shear-Tension Interaction Relationship of Headed Stud. China J. Highw. Transp. 2015, 28, 80-86. 
28. Lin, Z.; Liu, Y.; He, J. Behavior of stud connectors under combined shear and tension loads. Eng. Struct. 2014, 81, 362-376. [CrossRef]

29. Eligehausen, R.; Fuchs, W.; Sippel, T.M. Anchorage to concrete. Struct. Eng. Mater. 1998, 1, 392-403. [CrossRef]

30. Eligehausen, R.; Mallée, R. Befestigungstechnik im Beton-Und Mauerwerkbau; Ernst \& Sohn: Berlin, Germany, $2000 ;$ ISBN 3433011346.

31. Yan, J.B.; Liew, J.R.; Zhang, M.H. Shear-Tension Interaction Strength of J-Hook Connectors in Steel-Concrete-Steel Sandwich Structure. Adv. Steel Constr. 2015, 11, 72-93.

32. 91.010.30; 91.080.10; 91.080.40 (DIN EN 1994-1-1:2010); Eurocode 4: Bemessung und Konstruktion von Verbundtragwerken aus Stahl und Beton: Teil 1-1: Allgemeine Bemessungsregeln und Anwendungsregeln für den Hochbau. Beuth: Berlin, Germany, 2010.

33. Claßen, M.; Gallwoszus, J.; Hegger, J. Einfluss von Querrissen auf das Schubtragverhalten von Verbunddübelleisten in schlanken Betongurten. Beton-Und Stahlbetonbau 2014, 109, 882-894. [CrossRef] 